\title{
Diferencias y racismos: posibilidades y derivaciones de los etnocentrismos actuales
}

\author{
Eduardo L. Menéndez \\ Centro de Investigaciones y Estudios Superiores \\ en Antropología Social (CIESAS) \\ emenendez1@yahoo.com.mx
}

\begin{abstract}
Resumen: Este texto trata básicamente dos problemáticas complementarias: una referida al racismo y otra en la que desarrollo críticas a corrientes teóricas generadas entre 1970 y 1990. En el caso del racismo, si bien consideramos que es previo al desarrollo del capitalismo, sostenemos que ha constituido hasta la actualidad una de las principales estrategias de exclusión, subordinación y hegemonía del sistema capitalista, inclusive durante el periodo neoliberal. Subrayamos la continuidad etnocentrismo/racismo, dado que en determinadas situaciones los etnocentrismos inherentes a toda sociedad pueden derivar hacia distintas formas de racismo. Correlativamente, sostenemos que las corrientes teóricas señaladas se caracterizan no solo por ignorar el racismo, sino por su relativismo, ahistoricismo y presentismo, y que estas pueden ser usadas por las políticas neoliberales a través del papel dado a las diferencias, por la escasa referencia o directamente desinterés por las desigualdades socioeconómicas, así como por su negación de la problemática de la verdad.
\end{abstract}

Palabras clave: racismo, etnocentrismo, teoría antropológica, capitalismo

Abstract: This text basically addresses two complementary issues: one is racism and the other is a criticism of theoretical trends generated between 1970 and 1990. In the case of racism, which we consider to have been in existence before the development of capitalism, we argue that, to date, it has been one of the principal strategies of exclusion, subordination and hegemony, even during the neoliberal period. We place particular emphasis on the ethnocentrism/racism continuity, because in some situations the ethnocentrism inherent in all societies can lead to various forms of racism. We also argue that the theoretical currents mentioned here not only ignore racism, but are ethnocentric, a-historic and characterized by 'presentism.' These features can be used by neoliberal policies to give role to differences, to make a rare reference or even express indifference towards inequalities, and to deny problems of truth.

Keywords: Racism, ethnocentrism, anthropological theory, capitalism 
Hay una serie de problemáticas que me han preocupado persistentemente, y no solo a través de mis estudios y reflexiones, pero que las he vivido y sigo viviéndolas cotidianamente, frecuentemente de forma inesperada, aunque la mayoría de las veces puedo presuponer que en algún momento van a aparecer. Así, por ejemplo, el racismo normalizado ha constituido uno de los ejes constantes de mis preocupaciones, tanto por su persistencia como porque, pese a todas las demostraciones y evidencias científicas que lo han cuestionado, sigue operando en los más diferentes contextos, lo que - junto con otras problemáticas- me ha hecho plantearme recurrentemente el papel del quehacer científico. Es decir, ¿qué pueden hacer tanto las ciencias biológicas como las ciencias sociales, si, pese a demostrar hasta el cansancio que ningún racismo tiene base científica, dichos racismos siguen existiendo como parte de la vida cotidiana, a veces, solo como discriminación xenofóbica, y otras, a través de agresiones físicas que pueden concluir en masacres? ${ }^{1}$

Tal vez una de las posibles explicaciones radique en el papel contradictorio que tanto las ciencias llamadas duras como las antropológicas han tenido respecto al racismo, ya que simultáneamente lo han cuestionado, pero también lo han fundamentado en una historia más o menos interminable que llega hasta la actualidad. Pero quizás también tenga que ver con la vida cotidiana de los intelectuales $-y$, por supuesto, de otros actores sociales- que cuestionan el racismo a nivel de discurso, y lo practican a nivel de sus formas de vida.

Hace más de veinte años, un director del Instituto Gramsci de Italia llegó a México para impartir conferencias y participar en mesas redondas en el CIESAS-DF. Participé en una de esas mesas redondas junto con él y con otros intelectuales asumidos todos como gramscianos. Después de una mañana de conferencias individuales y colectivas, fuimos a comer a un restaurante. Durante la comida, el director del Instituto Gramsci me preguntó si yo era de familia italiana; cuando le dije que sí, ya que mis abuelos maternos eran calabreses, espontáneamente dijo en italiano gente bruta (gente fea), lo que me hizo recordar una película protagonizada por Nino Manfredi sobre los pobres, malos y

1 Este texto está básicamente desarrollado y pensado a partir de nuestros análisis sobre procesos de salud/ enfermedad/atención-prevención observados en México y otros países latinoamericanos, aun cuando la información presentada refiere muy escasamente a dichos procesos. Pero fueron estos los que nos posibilitaron observar varios de los aspectos que analizamos, dado que compartimos las ideas de varios gramscianos italianos de los sesenta y setenta respecto de que los procesos de s/e/a-p constituyen algunos de los "principales espías» de las contradicciones no solo del capitalismo y de otros sistemas sociales, sino también de los que analizamos dichas contradicciones. 
feos marginales urbanos del sur de Italia, es decir, sobre «la cuestión meridional», como diría Gramsci, pero, sobre todo, me hizo reflexionar sobre la brutal distancia que existe entre lo que escribimos y lo que hacemos. Lo grave, o tal vez miserablemente paradójico, es que el racismo inconsciente emergía en las opiniones del director de un instituto que tenía como uno de sus objetivos el estudio del papel de las clases subalternas en términos de hegemonía/contrahegemonía y no solo de subalternidad; clases subalternas del sur de Italia - los llamados terrone de la Calabria Saudita o de la Basilicata- que justamente fueron racializadas históricamente por gran parte de los italianos.

En abril de 1976, debido al golpe militar ocurrido en Argentina, decidí exiliarme en México, país que elegí por varias razones: la primera, porque quería permanecer en América Latina, y la segunda, porque México era el país latinoamericano con mayor desarrollo de nuestra disciplina. Pero, además, elegí México debido a que, a través de lecturas antropológicas y no antropológicas, emergían ciertas imágenes como la virgen morena de Guadalupe, la iconografía de la revolución mexicana y, en especial, del zapatismo, así como la existencia de Juárez como primer presidente de origen indígena, que me llevaron a pensar que México era un país exento de racismo.

En el año de mi arribo a México y en los tres años siguientes coordiné una serie de modestos estudios sobre medios de comunicación masiva y procesos de salud/enfermedad/atención-prevención. Lo más relevante que surgió en dichos trabajos (Menéndez, 1982) es el racismo que evidenciaban los medios de comunicación masiva, dado que todas - y subrayo todas - las imágenes publicitarias referían a mujeres y a varones de piel blanca y cabello rubio, en un país donde la inmensa mayoría de la población tiene piel morena y cabello negro (Menéndez, 2001).

Como fui constatando en mi vida cotidiana, oficialmente no existe racismo en México, pero este aparece en las reuniones sociales, en los restaurantes, en la entrada a discotecas, así como en la relación entre médico y paciente y en la exclusión de niños indígenas en cierto tipo de escuelas. Pero lo interesante es que la negación oficial de la existencia de racismo se articula con una antropología que - como casi toda la antropología latinoamericana - se caracteriza por estudiar muy escasamente el racismo (Castellanos, 2000). En la mayoría de las etnografías que conozco dedicadas a describir los pueblos originarios, la cues- 
tión racial no aparece, o, de aparecer, es solo mencionada, sin ser investigada, ${ }^{2}$ lo que nuevamente me llevó a plantearme el papel no solo de los intelectuales, sino especialmente de los antropólogos.

\section{Los principales aspectos del racismo}

Por este y otros motivos, siempre me han preocupado cuestiones como el rol de los intelectuales y de los profesionales y, en particular, la cuestión del racismo científico. Así como también me siguen preocupando los usos ideológicos de conceptos y teorías, los «olvidos» y la ahistoricidad de los científicos duros y blandos que, como veremos más adelante, se expresa a través de producciones académicas, que aun cuestionando el etnocentrismo y hasta el racismo de los demás, lo hacen a partir de posiciones etnocéntricas.

Pero, además, en los últimos años he descubierto un hecho obvio: posiblemente la característica política e ideológica básica del sistema capitalista es su constante pragmatismo, y uno de sus principales mecanismos de exclusión y subordinación, pero también de hegemonía, lo constituye el racismo.

Y es por ello por lo que, desde esta y desde otras problemáticas, considero que el pragmatismo y los diversos racismos constituyen dos de las principales estrategias que han asegurado, por ahora, la continuidad/discontinuidad del capitalismo. Si bien la mayoría de las estrategias han sido reiteradamente analizadas, considero que no se ha reconocido el papel de las señaladas en asegurar la continuidad capitalista, sobre todo, en su fase neoliberal. Tanto el fenomenal pragmatismo de los líderes políticos, de los empresarios y de los intelectuales orgánicos del capitalismo (George, 2007), como la generación y uso de ideologías aparentemente no políticas, pero que son usadas como mecanismos sociales e ideológicos que pueden ser adaptados a diferentes procesos y sujetos sociales, como es el caso del racismo, han acompañado el desarrollo del capitalismo a través de toda su trayectoria.

Las múltiples variedades de racismo se convierten en imprescindibles para establecer no solo diferencias, sino inferioridades y superioridades no ocasionales, sino definitivas. Y, por eso, el racismo siempre está disponible cuando los sectores dominantes, y también ciertos sectores subalternos, necesitan ex-

2 Es notorio el número de investigaciones y seminarios que los antropólogos han dedicado al estudio del cuerpo, pero entre nosotros casi no existen trabajos sobre los cuerpos racializados. 
cluir, inferiorizar o subordinar a otros, así como reforzar la propia identidad deteriorada o amenazada, como está ocurriendo actualmente en varios países europeos.

Posiblemente, los aspectos del racismo que más me han impactado son tres. En primer lugar, su permanencia hasta la actualidad a través de la construcción de acciones y de estereotipos estigmatizantes respecto de la población amerindia, de los afroamericanos, de los inmigrantes o de los judíos, que con pocas modificaciones son los mismos estereotipos que encontramos en el siglo XVI, a fines del siglo xix y en la actualidad. Los racismos se caracterizan porque pueden emerger $y$ ser utilizados para discriminar, explotar $y$ hasta exterminar a sectores sociales muy distintos, aunque casi siempre pertenecientes a los sectores subalternos o a los caracterizados por su alta vulnerabilidad social.

Un segundo aspecto tiene que ver con la colaboración de muy diferentes actores sociales en el desarrollo, mantenimiento y uso de los racismos, incluido el papel de los propios racializados. Desde esta perspectiva, me sigue sorprendiendo cómo los propios estigmatizados hacen suyas las concepciones racistas que los estigmatizan. Me sigue impresionando no solo el mantenimiento de los mismos estereotipos, sino el papel que las víctimas cumplen en esa autodenigración, lo que constituye una de las máximas expresiones de las relaciones de hegemonía/subalternidad.

Y el tercer aspecto se refiere no solo a la negación de nuestros propios racismos, sino a la tendencia a pensar que el racismo siempre está en los otros; y así los latinoamericanos consideramos casi unánimemente que los Estados Unidos es un país racista, mientras que nosotros (latinoamericanos) no lo somos. Estereotipo que, por ejemplo, se expresa en las formas en que hacemos antropología, ya que gran parte de los trabajos antropológicos que conozco respecto de la migración de latinoamericanos a los Estados Unidos dan cuenta con minuciosidad de los problemas que los migrantes tienen en sus intentos de migrar y asentarse en los Estados Unidos, incluidas las acciones racistas y la legislación antimigratoria de dicho país. Esto, en gran medida, es correcto, pero dichas afirmaciones se hacen generalmente sin comparar con lo que en varios de nuestros países hacemos con los migrantes no solo de otros países, sino también con los propios migrantes nacionales.

En México se está desarrollando desde hace unos cuatro o cinco años un pequeño movimiento encabezado por el sacerdote católico Solalinde que trata 
de concienciar a la población mexicana, y en particular al gobierno, sobre las formas en que son tratados los migrantes centroamericanos a su paso por México para llegar a los Estados Unidos.

La trayectoria migratoria incluye robos, violaciones sexuales, secuestros y asesinatos individuales y masivos de inmigrantes, generalmente realizados por grupos organizados. De hecho, esta problemática detonó hace pocos años, cuando se encontraron en el noreste de México varias fosas consideradas clandestinas con ochenta y cuatro cadáveres de migrantes torturados y asesinados.

Además, es decisivo asumir que todos los racismos obedecen a procesos culturales, sociales, económicos y políticos, por lo que no debemos confundir el uso de indicadores físicos y biológicos para racializar a grupos sociales y a sujetos, con que existen racismos de tipo biológico. Máxime cuando indicadores biológicos fueron aplicados por los españoles por lo menos desde el siglo $\mathrm{xV}$ a musulmanes - que no olvidemos siguen siendo moros para una parte de los españoles-, a judíos y, más tarde, a los indios americanos a través de la llamada limpieza de sangre. Que estos indicadores biológicos refirieran a concepciones religioso-políticas no niega que fueran utilizados para racializar con objetivos de dominación; así como el Reino Unido, los Estados Unidos, Suecia o Alemania utilizaron indicadores biológicos durante los siglos xIx y xx para explotar económicamente a ciertos sectores sociales, para esterilizar a otros o para exterminar por razones ideológico-políticas o científicas a ciertos grupos cuya vida «no merece ser vivida».

Por último, subrayo que desde una perspectiva antropológica los racismos no pueden ser separados de, por lo menos, algunos de los procesos que son observados en términos de etnocentrismo, pero también de relativismo cultural. Y no solo porque gran parte de los procesos etnocéntricos expresan clara o larvadamente tendencias racistas, sino porque todo relativismo puede constituirse o concluir en racismo. Etnocentrismo y relativismo son conceptualizaciones que, en última instancia, se resuelven no tanto en el plano de las interpretaciones teóricas o de los datos etnográficos, sino en términos de poder (Menéndez, 2010). Cuando los europeos, como analizan Said (1996) y otros autores (Abdel-Malek, 1963), inventaron durante el siglo xvir el término Oriente, lo desarrollaron tanto en términos positivos como negativos a partir de criterios etnocéntricos; pero ocurre que tanto Said como las corrientes etnicistas y las decoloniales que utilizan negativamente el término Occidente también lo 
hacen etnocéntricamente. Que dichos etnocentrismos concluyan o no en racismos dependerá de los procesos que se desarrollen y de las tácticas sociales que se utilicen. ${ }^{3}$

El supuesto de que solo Occidente y el capitalismo han generado y utilizado el racismo no solo es incorrecto, sino que es parte de dos juegos intelectuales: el que se da entre relativismo y etnocentrismo, que señalamos previamente, y los juegos teoricistas que practican las corrientes post, y especialmente las autodenominadas decoloniales y últimamente postoccidentales. Como todos sabemos, la esclavitud es un sistema de relaciones sociales, étnicas, económicas y de género utilizado por el capitalismo desde sus inicios hasta la actualidad. Pero este sistema es previo al capitalismo, y la esclavitud implica la existencia de sujetos inferiores y superiores; supone usar a los otros sujetos como cosas, y puede suponer la exterminación de los sujetos considerados esclavos. Una de las esclavitudes —o si se prefiere trabajo forzado- más antiguas, y que no vamos a tratar ahora, es la esclavitud de género expresada, sobre todo, a través de distintas formas de prostitución, que también siguen siendo utilizadas por el capitalismo, pero que también son previas a él. ${ }^{4}$

Por estos y por otros procesos, considero el racismo una de las ideologías más eficaces desarrollada y aplicada por varios sistemas, incluido el capitalismo, en sus diferentes fases y contextos; y ello es en gran medida porque, dada su diversidad, puede ajustarse a las variantes pragmáticas que necesitan aplicar las sociedades capitalistas. Es posiblemente la ideología que más ha contribuido a establecer los criterios de inferioridad y superioridad con que se categoriza a los diferentes sujetos sociales, constituyendo uno de los más persistentes mecanismos de hegemonía/subalternidad generado por las sociedades capitalistas

\footnotetext{
3 La psicología social norteamericana, especialmente en los cincuenta y sesenta, demostró que todo sujeto y grupo social genera estereotipos etnocéntricos como formas de orientación y acción básica en su vida cotidiana; es decir, constituyen procesos normales en el desarrollo individual y colectivo (Allport, 1962; Asch, 1964). Dichos estereotipos se reforzarán, se reducirán o se modificarán en las experiencias de sujetos y grupos, y dependerá de múltiples factores que dichos estereotipos etnocéntricos se apliquen en términos positivos o deriven hacia acciones negativas, incluidas las racistas. Estos tempranos aportes han sido confirmados y profundizados ulteriormente por el interaccionismo simbólico y por la teoría crítica de la desviación (Menéndez, 1979).

4 A finales de mayo de 2014, la Organización Internacional del Trabajo informó que el trabajo forzoso e ilegal genera al año 150.000 millones de dólares a nivel mundial. Casi dos tercios de esas ganancias $(99.000$ millones de dólares) proceden de la prostitución forzada, la cual constituye el principal rubro del trabajo forzoso mundial, especialmente en países asiáticos y, en segundo lugar, en las economías desarrolladas, incluyendo los países de la Unión Europea (La Jornada: 01/06/2014).
} 
tanto en términos de clase social, como en términos de relaciones coloniales. Es posiblemente uno de los procesos que más ha contribuido a realizar y legitimar masacres como la generada por el nazismo alemán, pero subrayo que focalizar el racismo casi exclusivamente en la exterminación hitleriana puede conducir a que lo observemos como un problema excepcional, pese a que aplicamos y reproducimos el racismo constantemente a través de nuestros comportamientos diarios.

Considero que la mayoría de los racismos han sido normalizados en nuestras sociedades, y que se ejercen y se reproducen en la vida cotidiana a través de los procesos e instituciones más disímiles. Y así, por ejemplo, entre mediados de los setenta y mediados de los noventa se aplicó en la mayoría de los países latinoamericanos una política de planificación familiar que posibilitó la esterilización sin consentimiento de mujeres y, en mucho menor grado, de varones. Fue una política de estado que, sobre todo en ciertos países, operó especialmente sobre mujeres indígenas y afroamericanas. Y esta política se aplicó oficialmente a través de las secretarías y ministerios de salud, es decir, fue aplicada a través de criterios técnicos, profesionales y científicos, donde podemos constatar una vez más el papel de las ciencias y los profesionales biomédicos en acciones de tipo racista. Los países latinoamericanos en los que se aplicó sistemáticamente esta política a millones de mujeres (Menéndez, 2009) son Brasil, Colombia, Costa Rica, Ecuador, El Salvador, Guatemala, Honduras, México, Nicaragua, Panamá, Perú, Puerto Rico y República Dominicana, es decir, casi todos los países de América Central y Suramérica, y los pocos países que no aplicaron estas políticas fue porque tenían una baja tasa de natalidad y un escaso crecimiento demográfico.

El uso de las ciencias con objetivos racistas no reconocidos como tales forma parte del denominado proceso de occidentalización, proceso que, pese a la crisis económica y, según algunos autores, también crisis hegemónica, sigue expandiéndose y operando a través de aspectos no solo científicos, sino culturales y económicos. Como ya señalamos, el término Occidente ha sido propuesto en términos ideológicos por toda una serie de autores y tendencias etnicistas africanas, asiáticas y latinoamericanas que oponen esta categoría a categorías como Oriente - o como negritud - utilizada frecuentemente en términos racistas o etnocéntricos por el pensamiento occidental. La categoría Occidente manejada actualmente por las tendencias anticolonialistas refiere no solo al capitalismo 
en términos económicos, sino sobre todo en términos culturales, implicando que toda una serie de lacras morales y sociales constituyen parte intrínseca del capitalismo como sistema cultural y no solo económico.

Pero ocurre que toda una serie de corrientes ideológicas y, en algunos casos, políticas que se han desarrollado desde la conclusión de la denominada Segunda Guerra Mundial hasta la actualidad han saturado de contenidos racistas sus críticas al capitalismo y al occidente blanco. Y esto lo podemos observar en las propuestas y acciones del denominado poder negro en los Estados Unidos en la década de los cincuenta; así como en determinadas propuestas indianistas y etnicistas como las de Fausto Reinaga $(1974,1978,1982)$ para Bolivia entre los cuarenta y los noventa. Si bien podemos entender dichas propuestas como respuestas y estrategias descolonizadoras, estas no solo adquieren caracteres racistas, sino que generan lecturas distorsionadas del desarrollo capitalista.

$\mathrm{Y}$ así, por ejemplo, me sorprenden las expectativas colocadas en la actual China y en los países del denominado BRICS, ${ }^{5}$ como si estuvieran modificando las estructuras y objetivos capitalistas dominantes, cuando lo que están impulsando - pese a que la mayoría no son occidentales - son formas tradicionales de capitalismo, que en el caso de China constituye un capitalismo de estado, mientras algunos de los otros juegan a la oscilación entre liberalismo y mercantilismo con ciertas dosis de neokeynesianismo. Pareciera que dichas interpretaciones consideraran que, si el capitalismo estuviera en manos de culturas no occidentales, tendría la posibilidad de ser orientado hacia otras formas morales de explotación y dominación.

Por supuesto, no niego las ventajas económico-políticas coyunturales que los BRICS pueden generar, inclusive para varios países latinoamericanos, pero en la medida en que también reparemos en las consecuencias socioambientales negativas de las actividades económicas extractivas que impulsan varios de esos países y asumamos que varios de los miembros de los BRICS se caracterizan por ser algunos de los países que a nivel mundial tienen las más fuertes desigualdades socioeconómicas y los gobiernos más corruptos o dictatoriales.

Ahora bien, las expectativas colocadas en los BRICS podrían ser consideradas como una astucia más del capitalismo, cuando lo que expresa es, sobre todo, su fenomenal pragmatismo. Pragmatismo a través del cual las sociedades capitalistas han tratado de superar las crisis económicas cíclicas, así como las 5 El BRICS está integrado por Brasil, Rusia, India, China y Sudáfrica. 
cruentas luchas interimperialistas, los procesos de descolonización y la constitución de bloques políticos antagónicos al capitalismo, como en su momento fueron los denominados socialismos reales. Desde esta perspectiva, para nosotros, el desarrollo del capitalismo no tiene que ver con ningún esquema evolucionista ni neoevolucionista, sino con un pragmatismo que utiliza todos los mecanismos, fuerzas, medios y actores sociales que aseguren su continuidad. Y, por eso, también resultan sorprendentes las aseveraciones de que, dada la actual crisis, recesión o erosión de los estados de bienestar europeos «estamos regresando a finales del siglo XIX»; ya que considero que no estamos regresando a ningún siglo XIX ni Xv, sino que el capitalismo, cuando se ve obligado - o cuando puede-, opta por las formas capitalistas que más le convengan, ya sea el mercantilismo proteccionista, el liberalismo económico, o el estado de bienestar. También puede jugar a las democracias parlamentarias europeas o a las dictaduras latinoamericanas, según convenga a los sectores dirigentes y, por supuesto, dependiendo de las acciones de los sectores sociales subalternos que transaccionan con ellos, incluidos enfrentamientos, resistencias y luchas.

De allí que tampoco entiendo las sorpresas actuales ante el surgimiento en varios países europeos de tendencias y hasta de partidos políticos de corte fascista, y ya no como grupos marginales, sino como fuerzas sociales, dado que los fascismos constituyen alternativas posibles, y no solo excepcionales episodios nefastos del pasado reciente occidental. La única explicación que tengo ante estas sorpresas se refiere al domino de concepciones ahistóricas y neoevolucionistas en parte del pensamiento actual.

Más aún, dado que las adecuaciones capitalistas son cada vez más frecuentes después de la Segunda Guerra Mundial, una parte de los analistas considera que estamos ante la crisis final del sistema capitalista. Ahora bien, sin negar esta posibilidad, lo que observamos es una suerte de pragmatismo permanente no solo como respuesta de los países capitalistas a los nuevos acontecimientos históricos, sino como mecanismo para impulsar una mayor explotación económica, que es lo que estamos sufriendo en la fase neoliberal. ${ }^{6}$

Y este pragmatismo ejercido por una minoría, cada vez más minoritaria, es difícil no tanto de entender, sino de enfrentar; dado que dicho pragmatismo lo

6 En esta expectativa se suele confundir la pérdida de hegemonía - si es que la está perdiendo- de los Estados Unidos con la caída del capitalismo, cuando lo que estamos observando es tal vez un proceso de transición hegemónica como piensa Wallerstein, que por ahora no implica la desaparición del capitalismo, por lo menos a medio plazo, aunque es seguro que lo sea a larga duración. 
opera una minoría que, si bien tiene fuertes conflictos a nivel interno e internacional, tiene un objetivo económico común, y se organiza para ello, imponiendo al resto de la humanidad sus estructuras y sus organizaciones. Más aún, impulsa sus decisiones, y el resto de los sectores sociales se ven obligados a reaccionar constantemente frente a esas imposiciones económicas, militares o culturales. Y si bien este es un hecho obvio, no siempre nos acordamos de que, ante las compulsiones de cualquier sistema dominante y no solo del capitalista, las primeras reacciones de la mayoría de los sujetos y conjuntos sociales no son para enfrentarlo, sino para asegurar la supervivencia y frecuentemente un mínimo de supervivencia, para luego, si queda tiempo, organizarse, enfrentar, proponer y realizar alternativas. Considero que el dominio en el lenguaje académico y político actual del término resistir indica no solo la situación de recesión ideológica en la que estamos viviendo, sino la operación de encubrimiento retórico generada por gran parte de los analistas de los movimientos sociales. ${ }^{7}$

Las estructuras y agentes capitalistas operan como grandes sociópatas abstractos cuyas acciones tienen consecuencias no solo macroeconómicas, sino microsociales; es decir, operan en nuestra vida cotidiana. No hay ortodoxia capitalista, la única ortodoxia es el logro de la máxima tasa de ganancia y, para lograrlo, el capitalismo se adecua o construye las posibilidades que aseguren su objetivo. Sin embargo, dichas adecuaciones para la obtención de sus objetivos dependerán de su fuerza y, obviamente, de la fuerza de los actores sociales que lo enfrenten, es importante tomar en cuenta algunos procesos que los sectores críticos asumen solo muy de tanto en tanto.

\section{El redescubrimiento de lo ya sabido}

Creo que desde finales de la década de los sesenta tomé conciencia de un hecho social que se reitera históricamente, pero del que parece ser que solo los sectores sociales dominantes han sacado conclusiones operativas. Y me refiero al hecho

7 Mientras que en los sesenta y parte de los setenta una de las palabras más usada en términos políticos, pero también académicos, era la de lucha, y no solo referida a la lucha de clases, desde los ochenta será reemplazada por la de resistencia. Varias tendencias teóricas y políticas se han potenciado para utilizar el concepto de resistencia, que podemos sintetizar en la muy citada frase de Foucault: «Donde hay poder, hay resistencia». La pena es que Foucault no estudió las resistencias. Lo señalado, por supuesto, no niega los múltiples procesos de luchas, enfrentamientos, aguantes que existen en las diferentes sociedades, pero que no sabemos bien que expresan en la mayoría de los casos. Creo que en todo acto necesitamos establecer su sentido y objetivos, así como las consecuencias objetivas que genera, para decidir que significa ese acto, y no caer en las generalidades de Scott (2000), para quien casi todo acto puede ser un indicador de resistencia. 
de que una minoría de cientos o de miles de sujetos en muy diferentes contextos han evidenciado la capacidad de controlar y dominar a millones de sujetos. Y esto fue así durante la conquista y colonización de América, fue así durante la colonización inglesa de la India, fue así durante la colonización europea de toda África generada a fines del siglo xIX, y fue así en los campos de concentración nazi del siglo $\mathrm{xx}$. Y, en todos los casos señalados, dicho proceso de dominación no puede atribuirse a la omnipotencia de los medios, al consumismo, a la alienación de las masas o exclusivamente al empleo de la fuerza física.

Justamente, yo asumí este hecho a partir de los campos de exterminio nazi, donde un pequeño grupo de soldados de elite pudo controlar, hacer trabajar y exterminar a millones de prisioneros no solo judíos sino gitanos, eslavos y de otros grupos nacionales y étnicos.

Más aún, en todos esos contextos, los grupos dominantes incorporaron como fuerza de control a miembros de los grupos colonizados y dominados, desde cipayos hindúes hasta kapós judíos. Y estos hechos no deben ser vistos como excepcionales, sino que necesitamos referirlos a las trayectorias normales de las distintas sociedades bajo el capitalismo, donde permanentemente un pequeño número de personas controla a millones de sujetos que, además, como ocurre actualmente en México, están en su mayoría en situación de pobreza y extrema pobreza o, por lo menos, de vulnerabilidad social.

En los últimos años se ha venido señalando el incremento de la concentración de la riqueza en pocas manos, más aún, se descubre que el 1 \% de la población concentra casi la mitad de la riqueza a nivel mundial (OXFAM, 2014), y que dicha acumulación no solo se incrementa desde la década de los setenta, sino que profundiza las desigualdades socioeconómicas, lo que detonó con la publicación reciente del libro de Piketty El capital. Obviamente, este constituye uno de los más claros ejemplos de lo que estoy señalando, por lo que, si bien muchos tenemos expectativas teóricas, emocionales o ideológicas de que esto estalle en algún momento, necesitamos asumir que los estallidos, según lo evidencian los estudios históricos, no solo son escasos en términos comparativos, sino que tanto los premeditados como los espontáneos suelen durar poco tiempo. Pero, sobre todo, necesitamos asumir y tratar de explicar por qué tan pocos sujetos y grupos pueden explotar y controlar a la mayoría de la población tanto en el siglo xvi como en la actualidad. Y subrayo mis dudas, o tal vez mis ignorancias, porque las propuestas explicativas, desde La Boétie hasta Lefort y 
Zizek pasando por Hegel, no me convencen, o tal vez no termino de entenderlas cuando las refiero a los procesos específicos que estudio.

A partir de dichos estudios y, sobre todo, de los procesos estudiados, considero que algunos de los principales mecanismos de sujeción de las clases subalternas son de tipo social y, sobre todo, ideológico, lo que no significa ignorar que los sistemas utilizan la fuerza, ya que la usan de forma tal que puede llegar a ser genocida, pero gran parte del uso de la fuerza es ideológica y social. Es decir, opera como una fuerza potencial, que en ciertos momentos se ejerce con terrible contundencia, pero que en la mayoría de los casos sabemos que está ahí, constituyendo, por lo tanto, un referente de lo que puede ocurrir, referente en el que se sustenta la persistencia de la fuerza como mecanismo ideológico.

El capitalismo no es sobrio ni hedonista en sí, sino que sus orientaciones morales y culturales dependerán de lo que va aconteciendo en su propia trayectoria $y$, por eso, considero que una guía metodológica consiste en rastrear las adecuaciones pragmáticas que las sociedades capitalistas generan en los diferentes campos de la realidad. Desde esta perspectiva, la realidad haciéndose a sí misma y sobre la marcha, desarrollada por algunas tendencias teóricas de los ochenta y noventa, tiene su mayor expresión no tanto en los diferentes sujetos sociales más o menos alternativos emergidos en esas décadas, sino en las formas a través de las cuales el capitalismo se desarrolla para asegurar su continuidad.

Un penúltimo episodio de este pragmatismo tiene que ver con uno de los procesos más mediáticos desarrollados especialmente durante los ochenta, noventa y primeros años del 2000, ya que durante el denominado neoliberalismo se produjo no solo una suerte de explosión de las diferencias y de nuevos actores sociales, sino una expansión, por lo menos en el discurso, de los derechos humanos. Si bien el surgimiento y reconocimiento de una parte de los nuevos sujetos sociales fue producto de sus luchas, los sectores sociales dominantes los verán también como consecuencia del propio neoliberalismo, dado que inicialmente la mayoría de los grupos autodesignados diferentes y que proponían el empoderamiento a partir de sus particularidades surgieron y lograron una parte de sus objetivos en los países capitalistas desarrollados y, especialmente, en los Estados Unidos. Esto reforzó la concepción de los intelectuales neoliberales, pero también de gran parte de los cuestionadores del neoliberalismo, de que los derechos humanos universales se habían gestado y desarrollado casi exclusivamente en las sociedades occidentales y bajo el capitalismo; lo que es 
así, más allá de cómo y para qué fueron y son usados dichos derechos por los diferentes actores sociales. Como en tantos otros procesos, los derechos humanos son parte de transacciones entre actores sociales disímiles y antagónicos, de tal manera que simultáneamente los gobiernos de los países capitalistas centrales y, en particular, los Estados Unidos se apropian de dichos derechos como mecanismo de control y de hegemonía, y los movimientos sociales se apropian de ellos también como mecanismo de negociación y de producción de alternativas ante la expansión neoliberal (Speed, 2012).

No cabe duda de que las propuestas y acciones para reducir el papel del estado y reconocer el papel de los sujetos, posibilitaron que los grupos que venían luchando por su reconocimiento y empoderamiento — como fueron el movimiento feminista o el movimiento homosexual, pero también los movimientos de los pueblos originarios americanos - lograran durante el neoliberalismo un mayor reconocimiento de su diversidad, así como ciertas cuotas de poder. Más aún, en varios países se generó no solo un reconocimiento, sino una legalización de demandas básicas como la del derecho al aborto en el caso del feminismo, el derecho al matrimonio oficial en el caso de homosexuales y lesbianas, y el reconocimiento de por lo menos una parte de sus derechos culturales y territoriales en el caso de grupos étnicos americanos.

Pero, además de que algunos de estos derechos no son aplicados o encuentran resistencia en los gobiernos, como ocurre actualmente con el derecho al aborto en México y en España, lo más significativo es que el reconocimiento constitucional de los derechos de los grupos indígenas latinoamericanos no ha generado, salvo en Bolivia y en menor grado en Ecuador, modificaciones sustantivas positivas en la vida de estos pueblos. Siguen siendo los grupos con los niveles más altos de pobreza, los que tienen las más altas tasas de mortalidad general y, por grupos etarios, los que tienen los menores índices de educación formal y los que más padecen discriminaciones raciales.

Esto, por supuesto, no niega que es mejor tener reconocimiento constitucional de los derechos culturales y de algunos derechos territoriales que no tenerlos; así como también es mejor tener gobiernos como el de la capital de México, que ampara el derecho al aborto, que padecer gobiernos como el del estado mexicano de Guanajuato, que ha aplicado recientemente penas que van desde los cuatro a los veinte años de prisión a mujeres que han abortado. Pero el eje, para mí, no está en la legalidad en sí, sino en la capacidad de movilización 
y de organización, para lograr que la legalidad se ejerza. Y esto en la mayoría de los países de América Latina es decisivo, y no solo en términos políticos y sociales, sino también teóricos. Ya que considero que, pese a que cuestionamos el evolucionismo y la idea de progreso, nos comportamos como si nos adhiriéramos a dichas concepciones, porque actuamos como si una vez conquistado el derecho al aborto, el derecho a la jubilación o el derecho a la cobertura de salud gratuita, estas permanecerán en adelante como un derecho adquirido; lo que desgraciadamente no es así, puesto que determinados sectores dominantes tratarán, apenas puedan, de modificar e inclusive eliminar esas conquistas que «logramos conseguir» y que considerábamos definitivas.

Esta tendencia a cuestionar teórica e ideológicamente grandes relatos como los del evolucionismo unilineal y la idea de progreso, pero aplicándolos, sin embargo, en nuestras vidas cotidianas, son parte básica de lo que denomino teoricismo. Pero, además, esta tendencia es parte del pragmatismo no solo del sistema dominante, sino de los sujetos que vivimos en él, dado que, como he señalado reiteradamente en varios trabajos, los sujetos y grupos, aun cuestionando el sistema social dentro del que vivimos, lo reproducimos a través de nuestra propia vida cotidiana.

Los señalados constituyen algunos de los aspectos centrales de lo que estoy proponiendo: por una parte, tratar de articular hasta lo posible nuestras representaciones teóricas y nuestras prácticas de vida, no solo para superar el teoricismo, sino para un uso más eficaz de las teorías. Por otra parte, entender los procesos sociales como transacciones entre los diferentes actores sociales; transacciones que generalmente se dan a partir de las imposiciones de los sectores dominantes que exigen luchas, enfrentamientos, negociaciones, resistencia $y$, sobre todo, activismo por parte de los sectores subalternos, en primer lugar, para no ser aún más explotados o excluidos, y, en segundo lugar, para modificar las relaciones de dominación. Y, por último, es esencial asumir el fenomenal pragmatismo de las formas capitalistas de dominación, que, como analizó Gramsci, tratarán no solo de apropiarse de la cultura de los sectores sociales subalternos, sino de hegemonizarlos a través de ellos mismos. Y recordamos que el racismo, tanto en términos etnocéntricos como relativistas, constituye uno de los principales mecanismos de dominación y de hegemonía, que ha tenido y sigue teniendo un papel protagónico en las relaciones de hegemonía y subalternidad dominantes en América Latina. 
Uno de los problemas que necesitamos enfrentar es que los racismos operan con demasiada frecuencia en las relaciones sociales donde no esperamos que operen, y así observamos que el racismo está presente en las relaciones que existen entre los propios grupos étnicos, así como también dentro de ciertas corrientes alternativas y contestatarias, como ocurre dentro del feminismo. Como sabemos, las corrientes feministas se gestaron sobre todo a partir de mujeres blancas de clase media en Gran Bretaña y en los Estados Unidos, siendo estas las que impusieron las líneas y objetivos prioritarios, que inicialmente no incluyeron las condiciones raciales ni de clase social - pero tampoco de pertenencia religiosa o de niveles educativos - dentro de las cuales operaban las mujeres. Solo focalizaron el género como un universal que estaba más allá de cualquier otro condicionamiento.

Pero, especialmente durante el neoliberalismo, las feministas de origen afroamericano, amerindio o de otras pertenencias étniconacionales —incluyendo las «blancas» - cuestionaron la exclusión de la clase social y del racismo, y afirmaron: «El racismo abunda en la literatura de las feministas blancas, reforzando la supremacía blanca... El rechazo histórico de las feministas a prestar atención y a atacar las jerarquías raciales ha roto el vínculo entre raza y clase (pese a que) la estructura de clases en la sociedad estadounidense se ha formado a partir de la política racial de la supremacía blanca» (Bell Hooks, 2004: 35 ).

Señalan que el feminismo nunca ha surgido de las mujeres que sufren las situaciones de clase y raza de forma más directa y cruel, subrayando que el discurso feminista blanco «rara vez se cuestiona si su perspectiva de la realidad de las mujeres se adecua o no a las experiencias vitales de las mujeres como colectivo. Tampoco son conscientes de hasta qué grado sus puntos de vista reflejan prejuicios de raza y clase...» (Bell Hooks, 2004: 35).

Un segundo problema es tratar de, por lo menos, controlar la tendencia a ver solo en el capitalismo toda una serie de procesos negativos, al asumir o connotar que los sistemas sociales previos o distintos son mejores en términos morales, contribuyendo con esta orientación no tanto a no comprender por qué los sujetos y grupos sociales actúan actualmente como actúan, sino a limitar la posibilidad de pensar otros mundos posibles sin presupuestos esencialistas que de entrada sesguen dicha posibilidad.

Justamente, una parte de las «feministas otras» cuestionan, aunque sin repudiarlas, sus sociedades originarias. Así, G. Anzaldúa analiza y denuncia la 
cultura dominante entre los chicanos, que la subalterniza como mujer a partir del machismo dominante. Una cultura que induce a la mujer a someterse al varón y a la madre del varón; una cultura que impulsa a la mujer a casarse y a tener hijos, pues si no lo hace constituye un fracaso como mujer; una cultura que considera que la mujer traicionó y vendió a su gente a los españoles, de tal manera que la criminaliza, justificando con ello la violencia y explotación ejercidas contra la mujer. La autora, si bien defiende la cultura en que nació, sostiene que « ... no glorificará aquellos aspectos de mi cultura que me han dañado, y que me hayan dañado con el pretexto de protegerme» (2004: 79).

Toda una serie de propuestas y de afirmaciones necesitan ser revisadas para no imponer concepciones esencialistas que excluyen a priori de los grupos subalternos estudiados o no estudiados acciones y representaciones sociales por considerarlas exclusivas del capitalismo. Si bien la expansión colonial, la Primera y Segunda Guerra Mundial y especialmente el nazismo condujeron a pensar los genocidios como exclusivo patrimonio de Occidente, lo cierto es que estos han estado y siguen estando presentes en numerosas culturas y sociedades no occidentales. Lo que ha agregado Occidente es una tecnología que posibilita una mayor eficacia y rapidez en los exterminios, tecnología que, por otra parte, fue y sigue siendo utilizada por grupos no occidentales. ${ }^{8}$

El tercer problema tiene que ver con los sucesivos asombros de muchos analistas respecto de cómo se comportan los gobiernos y empresarios capitalistas durante la trayectoria neoliberal, lo que evidencia que no han asumido el fenomenal pragmatismo del capitalismo que se ejerce a través de las más diversas instancias y actores sociales, o tal vez lo desconocen. El papa Juan Pablo II, como sabemos, desde la década de los ochenta trató de reducir al máximo los sectores del catolicismo que no solo cuestionaban al capitalismo, sino que trabajaban con los grupos sociales subalternos más perjudicados por la expansión neoliberal - y uno de esos sectores lo constituían nuestros grupos étnicos americanos-.

Esta política del Vaticano es correlativa de la expansión empresarial sobre territorios indígenas y, especialmente, sobre la región amazónica, donde no solo genera una depredación ambiental, sino la exterminación, migración y dislocación de una parte de los grupos nativos, lo que llevó a decir poco antes de morir

8 De lo que es expresión paradigmática el genocidio de la población armenia realizado por el estado turco en 1915-1916, y que supuso la eliminación de entre el 60 \% y el $80 \%$ de dicha población. 
a uno de los principales defensores de los derechos de los indígenas brasileños, O. Villa Boas: «Lo único que podemos hacer ahora es recoger el sombrero del abogado, y maravillarnos de que fuimos testigos de los últimos días del Edén» (Chalk y Jonassohn, 2010: 534). Esta penetración se ejerce en casi todos los territorios que todavía pertenecen a grupos subalternos indios y no indios de América Latina, con el apoyo de los gobiernos, empresarios locales y también de una parte de los pobres rurales y urbanos, lo que es absolutamente transparente en el caso de la región amazónica.

Ahora bien, respecto de lo que venimos señalando, es importante recuperar algunos análisis desarrollados durante la década de los noventa (Assies, Van der Haas y Hoekma, 1999; Favre, 1999 [1996]), según los cuales los gobiernos de los países latinoamericanos reconocían por lo menos una parte de los derechos indígenas, hablaban de multiculturalidad, interculturalidad y diferencias, proponían desarrollos sustentables, y no solo reconocían, sino que modificaban sus constituciones; sin embargo, simultáneamente desarrollaban no solo una constante penetración económica en territorios indios, sino también una continua profundización de las desigualdades socioeconómicas. Más aún, establecían formas de gubernamentalidad que, como señalan varios críticos, sobre todo, legitiman a los gobiernos, lo que no es parte de ninguna contradicción, sino que es parte del pragmatismo capitalista.

Además, los gobiernos locales y las agencias internacionales desarrollan procesos de apropiación conceptual al mismo tiempo que impulsan acciones reparativas respecto de las condiciones de pobreza que las políticas neoliberales están generando: «Es en el marco de la retirada del Estado de la política social que la noción de la participación y de empowerment — anteriormente reservada a los movimientos sociales y a las $\mathrm{ONG}$ - han hecho su aparición en el discurso gubernamental y son resignificados. Ciertos tipos de iniciativas locales, que surgieron inicialmente como proyectos de «autoayuda», respondían a la necesidad y tenían fuertes connotaciones de oposición al dominio autoritario, pero ahora son alentadas en nuevas maneras. A las ONG se les ha asignado un nuevo papel; algo así como el de «socios en el desarrollo». Mientras que los servicios públicos quedan dramáticamente reducidos, se hacen apelaciones a las organizaciones de la sociedad civil, es decir, a la variedad de organizaciones voluntarias financiadas principalmente por sus propios miembros, y a las redes de apoyo para mitigar los «efectos colaterales» negativos de las políticas 
de ajuste y encargarse de la educación, la salud o los servicios de extensión rural. Esto implica la privatización de esos servicios y la transposición de las cuestiones implicadas desde la arena política formal a la esfera social y, a la vez, el cambio de la responsabilidad del Estado a la sociedad civil (Taylor, 1998). La participación y el empowerment han sido incorporados en el discurso gubernamental, que trata menos de un cambio en las relaciones de poder y del control de los recursos, y más de la supervisión personal de ciudadanos responsables a través de sus esfuerzos en el mercado». Y concluye: «Mantener en mente esas propiedades del proceso de reformas del Estado provee una perspectiva crítica sobre aceptación de la diversidad cultural y de los logros de los movimientos de los pueblos indígenas» (Assies, van der Haar y Hoekema, 1999: 511-512).

Pese a que estas y otras acciones y apropiaciones son parte posible de los juegos políticos capitalistas, toda una serie de analistas latinoamericanos aparecen sorprendidos por estas aplicaciones de los gobiernos nacionales y de las agencias internacionales, denunciando que, pese a las modificaciones constitucionales logradas por las luchas de los pueblos indígenas, «los resultados no son satisfactorios», ya que los gobiernos y los organismos internacionales se han apropiado de las propuestas multiculturalistas y las han distorsionado. Sostienen, además, que no hay avances en la implementación de los derechos indígenas, dado el poco interés de los gobiernos en aplicar las modificaciones constitucionales: «Decepciona la doble moral con la que los Estados enfrentan el tema étnico-nacional en los países (latinoamericanos) estudiados. Por un lado, la legislación enarbola el reconocimiento de la diferencia, pero al mismo tiempo los Estados y su clase política dirigente despliegan estrategias políticas y económicas que minan las bases colectivas de los pueblos» (Burguete, 2008: 21). Concluyen que en Bolivia, Guatemala, México y Nicaragua las políticas culturales han contribuido, sobre todo, a legitimar a los gobiernos, lo que resulta interesante porque dos de estos gobiernos se caracterizan por cuestionar las políticas neoliberales.

Algunas analistas descubren que «el indigenismo en tiempos de multiculturalismo tiene muchas caras. Así, con ciertos segmentos de la población se mantiene políticas asimilacionistas, y con otros se reconoce los derechos a la diferencia cultural. De la misma forma, mientras que en algunas regiones las políticas indigenistas son omisas, en otras la presencia del Estado es densa y despliega estrategias que podríamos calificar de «insercionistas» (Burguete y 
Gómez, 2008: 349-50). Pero ocurre que esto siempre fue así, por lo menos desde mediados del siglo xix, cuando el capitalismo desarrolló políticas de gobierno directo e indirecto en sus colonias africanas y asiáticas, así como políticas asimilacionistas o de compartimentación tribal o comunalista, según le conviniera y, por supuesto, pudiera (Menéndez, 1969).

Además, también durante los ochenta y los noventa, varias tendencias consideraron que el desarrollo neoliberal suponía el repliegue y hasta casi la desaparición del Estado, dado que pensaban que, sobre todo, los neoliberales británicos y estadounidenses impulsaban el establecimiento de un «estado mínimo ». ${ }^{9} \mathrm{Y}$ pasaron a proponer que las empresas económicas multinacionales no solo no tenían responsabilidades ni identidades nacionales, sino que eran las verdaderas dueñas del proceso neoliberal, pensando que por ello ya casi no necesitaban de los gobiernos estatales. En el caso de los países dependientes, pensaron que la descentralización del estado en salud, educación y otros servicios, así como los procesos de privatización y la reducción de las políticas sociales, evidenciaban también el repliegue del estado. Y nuevamente comenzaron a sorprenderse cuando los gobiernos locales tanto neoliberales como populistas aplicaron programas y planes de apoyo especialmente contra la pobreza, y en varios casos no solo no redujeron sus inversiones en salud ni en educación, sino que las incrementaron. Más aún, la crisis desatada en el 2008 evidenció el papel decisivo del estado al rescatar, por ejemplo en los Estados Unidos, no solo a las instituciones financieras privadas, sino al conjunto de las empresas dedicadas a la producción de automotores. Y entonces comenzaron a hablar de las nuevas formas de «gobernabilidad».

También durante las décadas de los ochenta y noventa, la mayoría de los movimientos nativos y de los analistas de estos subrayaron los aspectos culturales, la pertenencia y diferencias étnicas, así como también ciertos aspectos políticos referidos especialmente a la autonomía, pero secundarizaron y hasta omitieron la cuestión de las desigualdades socioeconómicas.

Considero que, en muchos casos, la necesidad de subrayar la diferencia étnica obligó tácticamente a omitir la situación de clase, lo que posibilitó aún más reducir y hasta omitir la presencia de las desigualdades socioeconómicas, lo que

9 Just (2011) concluyó que, bajo la regencia de la primera ministra Thatcher, en el Reino Unido, el estado británico no se había debilitado, sino que se habían fortalecido varios de sus aspectos, incluida su capacidad de decisión política y económica. 
resulta paradójico porque fue durante dichas décadas cuando se incrementaron constantemente las desigualdades socioeconómicas generadas por la expansión neoliberal.

Pero, además, durante dicho lapso se incrementó la migración rural y urbana, de tal manera que en varios países latinoamericanos, incluido México, la mayoría de la población originaria vivía en medios urbanos, lo que hacía aún más difícil escindir lo étnico de la situación de clase. No obstante, la mayoría de las tendencias indianistas subrayaron las diferencias y no las desigualdades, en lo que fueron acompañadas por los gobiernos locales y por las agencias internacionales, que estuvieron de acuerdo en reconocer que las mujeres, los homosexuales y los grupos étnicos son diferentes. El énfasis en las diferencias no solo posibilitó opacar el incremento de las desigualdades socioeconómicas, sino que, al insistir en las pertenencias diferenciales y en las luchas particulares, limitó o imposibilitó la unificación de las luchas de los diferentes, y redujo la posibilidad de acuerdos favorables con los sectores dominantes. ${ }^{10}$

Desde principios del año 2000, como ya hemos señalado, retornan las preocupaciones por las desigualdades socioeconómicas, así como por el peso de los determinantes sociales. Comienza a quedar claro que las preocupaciones por estos, que predominaron entre las décadas de los cincuenta y los setenta, casi desaparecieron y fueron reemplazadas por la preocupación por las diferencias, justamente cuando se reinicia un nuevo periodo caracterizado por el constante incremento de las desigualdades socieconómicas y de la concentración de la riqueza en el $1 \%$ de la humanidad. Los trabajos de Piketty y de varios autores señalan desde finales de los noventa que es a partir de mediados de la década de los setenta cuando este proceso se reinició después de que durante el lapso 1913-1975 las desigualdades socioeconómicas se hubieran reducido significativamente, sobre todo, en ciertos países europeos y en los Estados Unidos, pero también en algunos países latinoamericanos.

Es decir, durante el lapso en el que las expectativas se colocaron no solo en las diferencias, sino en el papel contestatario de los movimientos sociales de todo tipo, lo que ocurrió fue que la reducida clase dominante volvió a imponer sus patrones de enriquecimiento y explotación. Observando, además, que los mismos analistas que daban por extinguido o en vías de extinción al

10 Recordemos que una parte de los analistas consideraron que esas dispersas luchas individuales posibilitaban no solo éxitos particulares, sino una mayor erosión del poder de las clases dominantes (Zibechi, 2008). 
capitalismo ahora descubren que «siempre no»; pero lo más preocupante es que algunos de los más destacados especialistas en movimientos sociales latinoamericanos concluyenः «Frente a la lógica del $1 \%$... debemos reconocer que aún no tenemos una estrategia para frenarla» (Zibechi, 2014).

Sin embargo, también va quedando claro que las nuevas formas de gobernabilidad no eran nuevas, sino solamente para los seguidores de Foucault, ya que la mayoría de ellas eran parte del repertorio de acciones que el capitalismo había venido desplegando. Su supuesta novedad no resiste la menor reflexión historizada y aún menos la confrontación con los datos empíricos, dado que, sobre todo, desde finales del siglo xix el capitalismo venía aplicando medidas sociales y económicas para poder asegurar su continuidad. Medidas que, en su mayoría no fueron voluntarias, sino producto de las relaciones de diferente tipo -incluidas protagónicamente las luchas sociales- que se generaron entre las clases dominantes y los sectores sociales subalternos. Las principales sociedades capitalistas se vieron obligadas a incrementar los salarios y a reducir los horarios de trabajo, aunque aplicando formas de trabajo fordista, y a establecer vacaciones pagadas, jubilación y otras prestaciones durante el lapso que va desde finales del siglo xix hasta mediados de los setenta.

Además, la mayoría de las nuevas formas de gobernabilidad se caracterizan en los países centrales por no ser represivas en términos de agresiones físicas, aun cuando funcionan dentro de políticas que pueden convertirse en represivas. Pero, además, dichas políticas no pueden entenderse si no se incluye la situación colonial que posibilitó mejorar los niveles de vida de una parte del proletariado de ciertos países europeos, sobre todo, en el rubro alimentación y que se expresó en el notorio incremento de la esperanza de vida (Stern, 1944; McKeown, 1976). Tampoco puede entenderse sin incluir el ascenso de las luchas obreras y descolonizadoras, y más tarde la constitución de los países autodenominados socialistas.

Más aún, las nuevas gobernabilidades recuperaron los antiguos programas contra la pobreza que resurgieron en los sesenta en países capitalistas metropolitanos, y que luego serían aplicados en países periféricos cuando las reformas estructurales del neoliberalismo comenzaron a incrementar la producción de pobres desde finales de los setenta. Producción de pobres que se daría, sobre todo, a nivel rural y especialmente en las zonas indígenas, y que generaría, por lo menos en parte, el surgimiento o reactivación de movimientos sociales deno- 
minados antisistémicos, incluidos los movimientos indígenas. Fue respecto del incremento de la pobreza y de las reacciones movimentistas que los gobiernos locales y las agencias internacionales no solo reconocieron las diferencias, sino que aplicaron programas sociales, que algunos consideran como nuevas formas de gobernabilidad.

Pero ocurre que las nuevas formas de gobernabilidad habían sido reflexionadas por Gramsci desde la década de los treinta como parte de las relaciones de hegemonía y subalternidad que los gobiernos de los países capitalistas desarrollados necesitaban implementar. Las nuevas gobernabilidades habían sido impulsadas no solo por los países capitalistas desarrollados desde finales del siglo XIX, sino que fueron impulsadas especialmente por la socialdemocracia alemana y francesa durante los veinte y treinta, por Roosvelt durante la década de los treinta y cuarenta en los Estados Unidos, pero también por los gobiernos fascistas de Mussolini y de Hitler desde las décadas de los veinte y los treinta respectivamente.

Como diría Gramsci, los bloques hegemónicos en cada país necesitaron reconocer y aceptar una parte de las aspiraciones, demandas, intereses y hasta concepciones de los grupos subalternos para incluirlos dentro de sus acciones, pero - y lo subrayo- a través de prácticas específicas y no solo de discursos. Más aún, trataron de apropiarse de las demandas y concepciones de los sectores subalternos para, a través de estas, dar continuidad a su hegemonía. Y esto, por supuesto, se da a través de transacciones sociales, pero que también incluyen condiciones y momentos de lucha y de represión (Menéndez, 1981).

\section{Presentismo, ahistoricidad y etnocentrismo}

Ahora bien, una parte de las corrientes teóricas actuales denominadas post, es decir, las que se desarrollaron desde la década de los ochenta hasta la actualidad, parecen haber redescubierto el racismo, pero, sobre todo, la situación colonial, ya que hasta algunas se autodesignan como decoloniales, pero ocurre que estas se caracterizan por un presentismo y tendencia a los olvidos, desconocimientos o exclusiones que evidencian la penetración que el neoliberalismo ha tenido, inclusive en aquellos intelectuales y corrientes teóricas que lo critican (Mignolo, 2001, 2011). Estas tendencias descubren hechos y formulan interpretaciones que se hicieron hace ya varias décadas, pero que están — digamos- olvidadas. 
Y ocurre, además, que los miembros de estas y otras escuelas actuales no solo desconocen estos aportes del pasado, sino que inclusive los critican, pese a que por la bibliografía que manejan, y que no manejan, evidencian desconocerlos.

La norma de las ciencias duras de que un texto científico tiene una vigencia no mayor de cinco años parece haber calado hondo en muchos científicos sociales. Y así una parte de los especialistas en diversidades, diferencias o nuevos sujetos sociales parecen no estar enterados de que antes hubo diversidades, diferencias y nuevos sujetos sociales, que tal vez en algunos aspectos fueron más eficaces que los sujetos sociales que ahora están descubriendo. Más aún, los estudios interculturales y multiculturales hacen propuestas y afirmaciones como si la interculturalidad y la multiculturalidad fueran procesos más o menos recientes.

Inclusive pareciera que los estudiosos poscoloniales son los que han descubierto no solo la situación colonial y sus consecuencias, sino las relaciones de hegemonía y subalternidad. Y así observamos que la corriente hindú de estudios subalternos desarrollada a partir de 1980, si bien reconoce la influencia de Gramsci, parece no tener idea de la producción académica y no académica italiana y latinoamericana que desde la década de 1940 analizó los procesos sociales e históricos en términos de hegemonía y subalternidad. Más aún, uno de los miembros del grupo hindú concluye en 1994: «El término subalterno aparece ahora con creciente frecuencia en investigaciones sobre África, América Latina y Europa, y los análisis de la subalternidad se han convertido en un campo en el que se pueden encontrar la erudición crítica en historia, literatura y antropología» (Prakash, 2007: 347). Que este autor ignore la producción latinoamericana puede tal vez ser entendible, pero que desconozca la extensa obra de los autores italianos gramscianos no solo expresa el etnocentrismo de parte de esta escuela de estudios de la subalternidad, sino también el peso de la hegemonía anglosajona a la que, se supone, esta corriente cuestiona, pero cuyo cuestionamiento parece que solo se reduce a la situación hindú.

Varias de estas corrientes generan, además, una recuperación unilateral de los análisis y propuestas de uno de los principales teóricos no solo del proceso de descolonización, sino del papel de la violencia. Recuperan especialmente los conceptos de Fanon referidos al encapsulamiento de los colonizados como mecanismo de resistencia anticolonial, pero sin analizar en qué concluyeron tanto estos conceptos como las realidades históricas que Fanon no solo describió y 
analizó, sino por las cuales luchó. Es decir, parecen no asumir que los conceptos tienen una historia no solo teórica, sino, como en este caso, política e ideológica, que en el caso de Fanon concluyó mal: la Argelia por la cual reflexionó, escribió y lucho terminó en algo muy distinto de lo que proponían y buscaron los que se enfrentaron al poder colonial francés, y establecieron la independencia argelina. Pero los autodenominados decoloniales y últimamente postoccidentales, en lugar de analizar por qué los conceptos y las acciones fanonianas concluyeron en lo que concluyeron, se dedican a incluir a Fanon en una genealogía antioccidental reflexionando, de paso, sobre las violencias decolonizadoras, a partir de juegos teoricistas tan frecuentes entre los académicos post.

Considero que, además de presentismo y desconocimiento, estos trabajos evidencian la persistencia de etnocentrismo inclusive en aquellos que lo cuestionan fuertemente. $\mathrm{Y}$ esto ocurre tanto en el pensamiento periférico como en el metropolitano, y en ambos casos se olvida o, por lo menos, no se incluye, lo que no solo autores, sino tendencias teóricas e ideológicas plantearon hace décadas, y que aún tienen vigencia. Y así, por ejemplo, un analista como Edward Said (1996), formulando críticas a la producción teórica occidental, concluye que los europeos no establecieron relaciones entre la cultura que generaron durante los siglos XIX y xx y el proceso imperialista dentro del cual se desarrolló dicha cultura; así como tampoco se preocuparon por las resistencias anticoloniales que se produjeron en el tercer mundo, incluidas las resistencias culturales a las cuales Said da un papel protagónico. Este autor recuerda que varias de las corrientes teóricas radicales producidas por los europeos ignoraron el papel del imperialismo y del racismo, y concluye: «La escuela de Frankfurt... mantiene un sorprendente silencio respecto a las teorías racistas, la resistencia antiimperialista y la oposición práctica dentro del imperio», recuerda inclusive las siguientes palabras de Habermas: «No tenemos nada que decir sobre las luchas antiimperialistas y anticapitalistas del tercer mundo» (1996:430). ${ }^{11}$ Según Said, la inmensa mayoría de los teóricos franceses e ingleses, incluidos Michel Foucault y Raymond Williams, no se interesaron por los procesos imperialistas y coloniales. ${ }^{12}$

11 Said parece desconocer el notorio interés por el racismo de varios miembros de la Escuela de Fráncfort, incluyendo la investigación coordinada por T. Adorno sobre la personalidad autoritaria (Adorno et alii, 1950), aun cuando dicho interés se concentró en el racismo antijudío.

12 Resulta llamativo que Foucault, en su descripción y análisis de las instituciones y mecanismos que crean e impulsan lo que este autor llama biopoder, ignore la situación colonial, ya que no se puede entender el 
El principal referente teórico de Said es Fanon, cuya obra ve como «una respuesta a las explicaciones teóricas ofrecidas por la cultura del capitalismo occidental, cultura recibida por el intelectual nativo del tercer mundo como una cultura de opresión y esclavitud colonial» (1999: 414). Pero ocurre que no solo el principal texto de Fanon, es decir, Los condenados de la tierra (1962 ), está prologado por Sartre, sino que tanto este como varios de sus otros textos evidencian fuertes influencias fenomenológicas, e inclusive el propio Said reconoce la decisiva influencia de Lukacs en Fanon. Más aún, Fanon se formó dentro de una izquierda occidental y, especialmente, dentro de un pensamiento francés que legitimaban la violencia de los sectores oprimidos, lo que se expresa paradigmáticamente en el prólogo de Sartre. Pero además, y es lo que quiero subrayar, Fanon fue sumamente leído en los cincuenta y sesenta e intelectuales latinoamericanos desde México hasta Argentina se apropiaron de él, en gran medida porque sus propuestas coincidían no solo con las discusiones que se estaban dando en aquellos años referidas al rol de la violencia, sino también con el posible papel contestatario de la población marginal y la recuperación de las culturas subalternas como importantes mecanismos de rehabilitación social y psicológica de los sujetos colonizados, así como de impugnación no solo cultural, sino política, de los poderes coloniales. Era un momento en el que seguíamos muy atentos el proceso de descolonización mundial, y especialmente el africano, para observar cómo iban resolviendo los problemas que enfrentaban para no caer en el neocolonialismo latinoamericano, aunque, no obstante, la casi totalidad de los estados africanos cayeron en él.

Y, por eso, resulta interesante observar la falta de referencias de Said a la situación y a la producción intelectual latinoamericana, y no solo porque Fanon hubiera nacido en las Antillas, sino porque varios autores latinoamericanos analizaron, teorizaron e impugnaron, por lo menos desde la década de los treinta, los procesos coloniales y neocoloniales, lo que es ignorado por Said. Más aún, varios de esos autores no solo hablaron de situación colonial y más tarde de colonialismo interno, sino que cuestionaron en particular la relación entre cultura neocolonizada e imperialismo. Y estos textos le podrían

biopoder de las sociedades metropolitanas sin asumir que gran parte de este se aplicó y se ensayó en los territorios coloniales. No solo la antropología se desarrolló en la situación colonial, sino que en los países centrales se crearon los institutos para el estudio de las enfermedades tropicales (sic), al igual que una parte de las concepciones eugenésicas y de los campos de concentración también se desarrollaron y aplicaron en la situación colonial. 
haber sido útiles a Said para comprender algunos de los problemas que más le preocupaban, como el papel negativo de las denominadas burguesías nacionales en el proceso de constitución del neocolonialismo africano, de lo que los latinoamericanos sabemos bastante y desde hace bastante tiempo.

Más aún, a través de la influencia de los tempranos y no tan tempranos trabajos de Balandier (1954/1955, 1971a, 1971b), pero también de autores gramscianos (ver Menéndez, 2010) se desarrolló en América Latina en los cincuenta, sesenta y principios de los setenta no solo una preocupación por el papel de las culturas subalternas, sino por la situación africana en particular. La teoría de la negritud, el denominado socialismo africano y el papel de los pueblos tribales interesó inicialmente a antropólogos como G. Bonfil, uno de los principales teóricos de los movimientos indios americanos, pero a partir de los setenta y sobre todo de los ochenta desaparece casi toda referencia al proceso de descolonización africano. Y desaparece paradójicamente cuando están emergiendo y pasando a primer plano los movimientos indianistas y etnicistas de América Latina, para quienes hubiera sido importante observar qué estaba pasando con los pueblos originarios africanos.

Inclusive resulta difícil comprender por qué los ideólogos de la indianidad latinoamericana no trataron ni tratan de analizar lo que elaboraron los africanos, ya que gran parte de sus propuestas son casi idénticas a las que ellos manejan, desde las que sostienen que en las sociedades africanas y andinas hay una democracia colectivista de base hasta la relación sagrada con la tierra, pasando por el desarrollo de conceptos comunes que se refieren al buen vivir. Pero sobre todo, porque gran parte de los problemas que emergieron en África son similares a los que tienen que resolver los pueblos originarios (Abdel-Malek, 1972; Burke, 1967; Diop, 2012; Dumont, 1966; Fanon, 2003 y 1968; Fridland y Rosberg, 1967; Jaffe, 1976; Mboya, 1963; Nkrumah, 1966; Woodis, 1968; Ziegler, 1969). Más aún, algunas concepciones utilizadas durante la primera década del 2000 por indianistas y, sobre todo, por los analistas, como la reserva comunal rebelde referida al repliegue indígena sobre sí mismo, constituye un claro concepto fanoniano; al igual que también lo son toda una serie de interpretaciones sobre los malestares emergidos en los grupos étnicos como respuesta a la dominación colonial.

Pero podemos también observar estos procesos de olvido, negación o exclusión en gran medida etnocéntricos constantemente en la producción académi- 
ca europea, incluidos varios de los intelectuales más consultados actualmente por el mundo periférico, como Zigmunt Bauman, quien en su extensa obra ha tratado, entre otros, el problema del denominado Holocausto, es decir, la política de exterminación de los judíos generada por Alemania bajo el nazismo; un problema estrechamente relacionado con varios aspectos que he señalado, $y$ especialmente con el racismo y con el papel de la ciencia en la fundamentación del racismo y en la eficacia de las acciones de exterminio.

En su libro Modernidad y Holocausto (1998), este autor analiza especialmente la relación entre Holocausto y modernidad, pero refiriéndola exclusivamente a la cuestión judía, y una de las afirmaciones fuertes de Bauman, pero también de la mayoría de los autores que tratan el Holocausto, es la de que «solamente los judíos estaban señalados para que se procediera a su destrucción total, y no tenían sitio en el Nuevo Orden Hitleriano» (1999: XIII). Y esto lo reitera en varias partes del texto, sin hacer la menor referencia tanto al extermino sistemático de los gitanos llevado a cabo por el nazismo, como a la situación colonial generadora de algunos de los etnocidios más extensos y profundos que se conocen. El nazismo decidió no solo la solución final de los judíos, sino también de los gitanos, ya que para la ideología nazi ambos pueblos se caracterizan por su trashumancia y migración constantes; es decir, por su falta de relación directa, permanente y sagrada con una tierra de pertenencia. Se calcula que por lo menos 600.000 gitanos fueron asesinados por el nazismo, que en términos porcentuales significa que fue el grupo humano más exterminado durante la Segunda Guerra Mundial, lo que obviamente no niega el terrible exterminio perpetrado por el nazismo contra la población judía.

Ahora bien, ¿cómo puede ser que un intelectual tan informado como Bauman se haya olvidado de que el grupo proporcionalmente más exterminado fuera el gitano, y no el pueblo judío? Si bien existe de forma muy extendida el antisemitismo, el antigitanismo es tan o más extendido aún, tanto en el pasado como en el presente europeo, ya que no solo siguen vigentes los estereotipos negativos contra este grupo, sino que también continúan las políticas de expulsión o de agresión hacia este, por lo menos en Alemania, Gran Bretaña, Eslovaquia, Francia, Hungría, la República Checa y Suecia. En este último país, entre 1934 y 1974, la esterilización de mujeres gitanas se constituyó en política de estado. Pero mientras el exterminio judío fue y sigue siendo estudiado de forma constante, mientras existe un país como Israel donde el Holocausto forma 
parte de la identidad nacional y de las políticas públicas, mientras países como Alemania han compensado a la población judía de sus crímenes de guerra, en el caso del Porrajmos (Devoración), que es el nombre que dan los gitanos a su exterminio, casi no hay nadie que lo estudie. No hay además un país gitano, ni hay organizaciones que denuncien no solo el exterminio pasado, sino las agresiones y desprecios actuales, y los defiendan de ello. Es decir, el «olvido» de Bauman de que el mayor exterminio impulsado por el nacionalsocialismo alemán es el de los gitanos expresa el etnocentrismo que sigue caracterizando, por lo menos, a una parte de la producción intelectual occidental.

Esta omisión de los gitanos en un libro dedicado al Holocausto generado por el régimen nazi resulta por lo menos interesante, pero además resulta incomprensible la falta de referencias a los exterminios generados en la situación colonial, sobre todo, porque Bauman considera no solo que el Holocausto es producto de la modernidad, sino que expresa sus límites y problemas. Para este autor, el extermino masivo es propio de una modernidad racionalizadora, ya que Auschwitz, el Gulag ruso y el bombardeo a Hiroshima, junto con el Holocausto, fueron actos de exterminio planificados. Pero ocurre que la expansión colonial, que en 1885 condujo a los países europeos a repartirse entre ellos el $90 \%$ del territorio africano de forma planificada, es también parte de una modernidad que utilizó la fuerza exterminadora más allá de toda moral. Como concluye Bauman, «la lección más importante del Holocausto tiene que ver con un proceso por el cual se despojó de todo cálculo moral la utilización y despliegue de la violencia, así como se libera de la interferencia de las normas éticas o de las inhibiciones morales» (1999: 37). Que fue justamente lo que caracterizó a la situación colonial.

A esta conclusión habían llegando varias décadas antes analistas del colonialismo y del racismo colonizador, y especialmente Hanna Arendt, quien sostuvo — teniendo presente el Holocausto-que el colonialismo racista «determinó las más terribles matanzas de la historia reciente, el exterminio de las tribus hotentotes por los Boers, los salvajes crímenes de Carl Peters en el África alemana del sudeste, la mortandad de la pacífica población del Congo, que de 20 millones fue reducida a ocho millones; y finalmente, quizás lo peor de todo, determinó la triunfal introducción de semejante medio de pacificación a la política exterior ordinaria y respetable» (Arendt, 1974:251). Por eso, la política de exterminio nazi constituye una continuidad de las políticas coloniales europeas 
y de los Estados Unidos, que utilizaron el racismo y la planificación como sus principales instrumentos de control y, cuando lo consideraron necesario, de exterminio. Una política colonial que, como señala Arendt, asoció racismo y burocracia, lo que posibilitó y justificó el tipo de dominio colonial y las masacres: «Nadie — señala Arendt - que de una forma o de otra estuviera implicado en su perfeccionamiento llegó a comprender toda la gama de potencialidades de acumulación de poder y de destrucción que por sí sola proporcionaba esta combinación» (1974:252).

No fue el nazismo el que inauguró las masacres planificadas, ni la negación de la moralidad dominante y su reemplazo por principios aparentemente amorales, sino que estos se constituyeron y desarrollaron durante la situación colonial. Necesitamos asumir en todas sus implicaciones que durante los siglos XIX y xx los funcionarios británicos declaraban que en África «no se permitirá que consideraciones éticas como los derechos del hombre se alcen en el camino de la dominación blanca» (Arendt, 1974: 290). El racismo justificó la eliminación de toda moral en las acciones que los blancos impusieron y siguieron imponiendo en varios contextos a los colonizados o, mejor dicho, establecieron una doble moral en prácticamente todos los planos de la realidad desde el trabajo hasta la sexualidad, pasando por la religión.

La articulación racismo/burocracia/planificación/transgresión de la moral dominante/ciencia se desarrolló por lo menos en parte en la situación colonial, y las consecuencias de esta articulación no fueron ocultadas, sino que solamente algunos aspectos fueron silenciados. $Y$ así fue silenciado el papel decisivo de las ciencias biológicas y médicas en la justificación eugenésica de ciertas esterilizaciones y en el desarrollo de una tecnología del exterminio; así como las ciencias antropológicas silenciaron hasta la década de los cincuenta las consecuencias de la situación colonial, incluidas las masacres. Y no olvidemos que las ciencias antropológicas eran las disciplinas encargadas de estudiar los pueblos colonizados, mientras los estaban explotando económicamente y, a veces, exterminando de forma directa o indirecta.

Los olvidos de Bauman contrastan con los reconocimientos desde Arendt hasta Judt, pasando por Traverso, de que la Alemania nazi aplicó a los territorios ocupados, especialmente a los de población eslava, las formas de dominación y extermino que las potencias europeas habían aplicado a los pueblos que colonizaron. Pero estos olvidos no son olvidos, sino que son expresiones de 
procesos etnocéntricos constitutivos de nuestros marcos teóricos, que operan más allá de que denunciemos los etnocentrismos de los otros, incluidos los racismos como las expresiones más extremas de etnocentrismo.

Los etnocentrismos y sus derivaciones racistas operan en diferentes instituciones, espacios y relaciones sociales, incluidas las académicas, y la cuestión principal, como he señalado en reiteradas ocasiones, es detectar quiénes son los racializados e, inmediatamente después, quién o quiénes pueden apropiarse y usar estos etnocentrismos y racismos explícitos o intersticiales, y no solo en las sociedades capitalistas. $Y$ es por ello por lo que me han preocupado y me siguen preocupando las concepciones y acciones racistas impulsadas por grupos y gobiernos de corte fascista o parafascista, así como también las concepciones y acciones racistas impulsadas por intelectuales, pero, sobre todo, por gobiernos que se consideraban a sí mismos comunistas, así como me preocupan las concepciones racistas desarrolladas en su momento por una parte del poder negro de Estados Unidos o por concepciones indianistas esencialistas, tipo Reynaga, desarrolladas en América Latina especialmente durante el neoliberalismo.

Los intelectuales y, aún más, los dirigentes sociales que juegan al etnocentrismos y a los racismos culturales, aun cuando sea como instrumentos tácticos de descolonización, deberían analizar no solo las consecuencias que pueden ocurrir, sino, sobre todo, establecer quiénes son los que pueden apropiarse y utilizar los etnocentrismos, incluidos los racismos esencialistas, impulsados con objetivos tanto colonialistas como descolonizadores.

Mientras las concepciones se mantienen a nivel de discursos, generalmente no ocurren consecuencias demasiado graves. El problema está cuando las concepciones son aplicadas sin que los grupos racializados cuenten con instrumentos y fuerzas para poder enfrentarlas. Necesitamos asumir que los poderes decisivos no están en los discursos ni en los cambios de narrativas, sino en los actores sociales que pueden utilizar dichas narrativas y, sobre todo, aplicarlas, en función del poder económico o político que tienen, incluido el poder del Estado. Pero, como señala reiteradamente Eagleton (1997, 2005), las corrientes post nos han ido acostumbrando a pensar la realidad, incluidos los racismos, exclusivamente en términos de discursos, de narrativas y de historias, pero no de prácticas sociales ni de desigualdades socioeconómicas, y menos aún en términos de verdad. 


\section{Bibliografía citada}

Adorno, T., E. Frenkel-Brunswik, D. J. Levinson y R. Nevit (1950), The autoritarian personality. New York: Harper \& Brothers.

Abdel-Malek, A. (1963), «Orientalismo en crisis» Diógenes, 44: 104-112.

Abdel-Malek, A. (1972), La dialéctica social. México: Fondo de Cultura Económica.

Allport, G. (1962), La naturaleza del prejuicio. Buenos Aires: Eudeba.

AnzaldúA, G. (2004), «Movimientos de rebeldía y las culturas que traicionan» en Bell Hooks et alii, Otras inapropiables. Feminismo desde las fronteras. Madrid: Traficantes de sueños.

Arendt, H. (1974), Los orígenes del totalitarismo. Madrid: Taurus.

Asch, S. (1964), Psicología Social. Buenos Aires: Eudeba

Assies, W., G. Van der Haar y A. Hoekema (1999), «La diversidad como desafío: una nota sobre los dilemas de la diversidad» en El reto de la diversidad. Pueblos indígenas y reforma del estado en América Latina. México: El Colegio de Michoacán.

Balandier, G. (1954/1955), L'Anthropologie appliquée aux problèmes des pays sous-développés. Paris: Université de Paris, Institut d'Etudes Politiques.

Balandier, G. (1971a), Sociologie actuelle de l'Afrique Noire. Dynamiques sociales en Afrique Central. Paris: Presses Universitaires de France.

Balandier, G. (1971b), Sens et puissance. Paris: Presses Universitaires de France.

Bauman, Z. (1998), Modernidad y holocausto. Madrid: Sequitur Ediciones.

Bell Hooks (2004), «Mujeres negras. Dar forma a la teoría feminista» en Bell Hooks et alii, Otras inapropiables. Feminismo desde las fronteras. Madrid: Traficantes de sueños.

Bell Hooks et alii (2004), Otras inapropiables. Feminismo desde las fronteras. Madrid: Traficantes de sueños.

Burguete, A. (2008), «Gobernar en la diversidad en tiempos de multiculturalismo en América Latina» en Leiva, X.; A. Burguete y S. Speed (Coord.), Gobernar (en) la diversidad: experiencias indígenas desde América Latina. Hacia una investigación co-labor. México: CIESAS/FLACSO.

Burguete, A. y M. Gómez (2008), «Multiculturalismo y gobierno permitido en San Juan Cancus, Chiapas: tensiones intercomunitarias por el recono- 
cimiento de 'autoridades tradicionales'» en Leiva, X.; A. Burguete y S. Speed (Coord.), Gobernar (en) la diversidad: experiencias indigenas desde América Latina. Hacia una investigación co-labor. México: CIESAS/FLAC$\mathrm{SO}$.

Burke, F. (1967), «Tanganica: en busca de Ujamaa» en Friedland, W. y C. Rosberg (Comp.) África socialista. México: Fondo de Cultura Económica. Castellanos, A. (2000), «Racismo, multietnicidad y democracia en América Latina», Nueva Antropología, XVII (58): 9-26.

Chalk, F. y K. Jonassohn (2010), Historia y sociología del genocidio. Buenos Aires: Prometeo.

Diop, CH. A. (2012), Naciones negras y cultura. Barcelona: Bellaterra.

Dumont, R. (1966), El África negra ha partido mal. Barcelona: Seix Barral Eagleton, T. (1997), Las ilusiones del posmodernismo. Buenos Aires: Paidós Eagleton, T. (2005), Después de la teoría. Barcelona: Debate.

Fanon, F. ( 1962), Los condenados de la tierra. México: Fondo de Cultura Económica.

Fanon, F. (1968), Sociología de la revolución. México: Era.

Friedland, W.y C. Rosberg (Comp) (1967), África socialista. México: Fondo de Cultura Económica.

Fuentes-Nieva, R. y Galasso, N. (2014), Working for the few. Political capture and economic inequality. Oxford: OXFAM International.

George, S. (2007), El pensamiento secuestrado. Cómo la derecha laica y la religiosa se han apoderado de Estados Unidos. Madrid: Público.

Jaffe, H. (1976), Del tribalismo al socialismo. México: Siglo XXI.

Judt, T. (2011), Postguerra: una historia de Europa desde 1945. México: Taurus. Leiva, X.; A. Burguete y S. Speed (Coord.) (2008), Gobernar (en) la diversidad: experiencias indígenas desde América Latina. Hacia una investigación co-labor. México: CIESAS/FLACSO.

Mвоуа, T. (1963), Libertad y futuro. Barcelona: Ariel.

McKwon, Th. (1976), The modern rise of population. London: Academic Press. Menéndez, E. L. (1969), «Colonialismo, neocolonialismo, racismo» Índice, 6: 72-94.

Menéndez, E. L. (1979), Cura y control. La apropiación de lo social por la práctica psiquiátrica. México: Editorial Nueva Imagen. 
Menéndez, E. L. (1981), Poder, estratificación y salud. Análisis de las condiciones sociales y económicas de la enfermedad en Yucatán. México: Ediciones de la Casa Chata.

Menéndez, E. L. (2001), «Biologización y racismo en la vida cotidiana» Alteridades, 21:5-39.

Menéndez, E. L. (2009), «De racismos, esterilizaciones y algunos otros olvidos de la Antropología y de la epidemiología mexicanas» Salud Colectiva, 5 (2): 155-180.

Menéndez, E. L. (2010), La parte negada de la cultura. Relativismo, diferencias y racismo. Rosario: Prohistoria (2. a ed. corregida y aumentada).

Menéndez, E. L. (Ed.) (1982), «Medios de comunicación masiva, reproducción familiar y formas de medicina popular» Cuadernos de la Casa Chata, 57.

Mignolo, W. (comp.) (2001), Capitalismo y geopolítica del conocimiento. Buenos Aires: Ediciones del Signo.

Mignolo, W. (2011), Historias locales/diseños globales. Colonialidad, conocimientos subalternos y pensamiento fronterizo. Madrid: Akal.

Nkrumah, N. (1966), Neocolonialismo, última etapa del imperialismo. México: Siglo XXI.

Prakash, G. (2007), «Los estudios de la subalternidad como crítica poscolonial» en S. Rivera y R. Barragán (Comp.), Debates Pos Coloniales. Una introducción a los estudios de la subalternidad. Bogotá: Universidad Surcolombiana.

Reinaga, F. (1974), América India y occidente. La Paz: Ediciones PIB.

Reinaga, F. (1978), Indianidad. La Paz: Ediciones PIB.

Reinaga, F. (1982), La podredumbre criminal del pensamiento europeo. La Paz: Ediciones Comunidad Amáutica Mundial.

Said, E. (1996), Cultura e imperialismo. Barcelona: Anagrama.

Scotт, J. C. (2000), Los dominados y el arte de la resistencia. Discursos ocultos. México: Ediciones Era.

Shrader-Frechette, K. (2004), «La justicia medioambiental, los pueblos indígenas y el problema del paternalismo» en J. L. Luján y J. ECheverría (Ed.), Gobernar los riesgos. Ciencia y valores en la sociedad de riesgo. Madrid: Biblioteca Nueva. 
Speed, S. (2012), «Ejercer los derechos/configurar la resistencia de las Juntas de Buen Gobierno Zapatista» en B. Baronet; M. Mora y R. Stahler (Coord.), Luchas 'muy otras'. Zapatismo y autonomía en las comunidades indígenas de Chiapas. México: UAM-Xochimilco.

Stern, B. (1944), Los progresos de la sociedad y de la medicina. Buenos Aires: Amercalee.

Wilkinson, Ch. (2013), Lucha de sangre. El ascenso de las naciones indias modernas, Quito: Ediciones Abya-Yala.

Woodis, J. (1968), África. Los orígenes de la revolución. Madrid: Ciencia Nueva.

Zibechi, R. (2008), Autonomía y emancipaciones. América Latina en movimiento. México: Sísifo ediciones.

Zibechi, R. (2014), «Una ojeada al uno por ciento», La Jornada 11/07/2014. Ziegler, J. (1969), La contrarrevolución en África. Barcelona: Lumen. 